\title{
The Influence of Sustainability Report Disclosure and Implementation of Good Corporate Governance on Earning Response Coefficient
}

\author{
Dewi Anggraini* Putri Renalita Sutra Tanjung \\ Department of Accounting, Universitas Mercu Buana, Indonesia
}

\begin{abstract}
This study aims to analyze the influence of disclosure of Corporate Social Responsibility and Good Corporate Governance to Earning Response Coefficient. The sampling technique used is purposive sampling. The research was conducted on the Mining Sector Company with the research period 2014-2016. The estimation of the research model used is multiple regression analysis. The results of this study are by the initial assumption that there is a positive correlation of the influence of CSR disclosure in a sustainability report to the informativeness of earnings (ERC), where the higher disclosure of CSR information indicates better corporate management signals, this ERC will also be higherGood Corporate Governance also has a positive effect on earnings quality calculated by ERC. The better the level of Good Corporate Governance owned by a company will weaken the action of the agent in making profit manipulation that is harmful so that the quality of earnings can increase.
\end{abstract}

Keywords: Corporate Social Responsibility, Good Corporate Governance, and Earning Response Coefficient

DOI: $10.7176 / \mathrm{EJBM} / 11-34-05$

Publication date: December $31^{\text {st }} 2019$

\section{Research Background}

The main aim of a company is to increase shareholder wealth through the optimization of corporate value (value maximization). In general, value maximization refers to the market value of equity, therefore for companies that go public related to the maximization of the stock market price. Many factors can affect stock prices, both internal and external factors of the company. Internal factors include financial performance, image, while external factors cover national and international economic conditions (Aryanti \& Sisdyani, 2016).

Environmental damage has been a severe problem in recent years. One of the economic subject which often becomes the cause of environmental issues is the company. For example, the smoke disaster caused by a forest fire in Indonesia that disturbs the surrounding community and even have an impact on foreign countries in 2015. Many companies do natural and human resources exploration to increase corporate profits. However, it will cause undesirable long-term implications. In the short term, the company's profits may increase, but on the other hand, the damage arising from the production process also increases, which will lead to costs for cleanliness, health, and environmental sustainability. It may result in degrading the company's image (Wulandari \& Wirajaya, 2014).

The development of information flow in the current era of globalization has led many companies in Indonesia to compete to improve the company's reputation in the eyes of society so that it can attract investors and maintain the survival of its business. Companies are expected to emphasize not only the interests of management and owners of capital (investors and creditors) but also employees, consumers, and society (Nurlis, 2017). Claims against companies to provide transparent information, accountable organizations and improved corporate governance (GCG) are increasingly forcing them to provide information about their social activities, one of them through sustainability reports. Sustainability Report increasingly becomes a requirement for the company to inform its economic, social and environmental performance as well as to all stakeholders (Aryanti \& Sisdyani, 2016). Sustainability Report contains not only financial performance information but also non-financial information which consists of information on social and environmental activities that emphasize the principles and standard of disclosures that can reflect the overall level of corporate activity to enable the company to grow sustainably.

Currently, the company is more required to provide accountability reports to stakeholders. The stakeholders are interested in understanding how the company's approach and performance are sustainable in various aspects, especially economic, environmental, and social elements, including the potential for creating corporate value through sustainable management. The disclosure of environmental, social, and financial performance in annual reports or separate reports is to reflect the degree of accountability, responsibility, and transparency of the company to investors and other stakeholders (Novita and Djakman, 2008). Therefore the company needs to create a sustainability report (Sustainability Report) which serves as a form of corporate responsibility to stakeholders in the way of a statement. Sustainability Report is published by companies or organizations on the economic, social, and environmental impacts of everyday activities (Initiative, 2013).

Sustainability Report itself is still voluntary, which means there are no rules that require companies to issue the Sustainability Report. In Indonesia, it has been described in the Statement of Financial Accounting Standards (PSAK) No.1 paragraph nine, which tells that "Companies can also present additional reports such as reports on 
the environment and value-added statements, especially for industries where the environment factors plays an important role and for the industry that considers employees as a group of report users who play important roles." Such a statement reflects that the Sustainability Report is still recommended for companies that want to publish the report. Although the voluntarily Sustainability Report has become an increasing trend and the requirement for companies to inform their economic, social and environmental performance as well as to all stakeholders (Chariri $\&$ Nugroho, 2009). This led to the emergence of various guidelines or guidelines provided by governments and international agencies to create guidelines on the Sustainability Report. One of the institutions that make the guidelines is the Global Reporting Initiative (GRI). The Global Reporting Initiative (GRI) is a non-profit organization in promoting economic sustainability. GRI produces worldwide standards for sustainability reporting such as Environmental Social Governance (ESG) Reporting, Triple-Bottom-Line (TBL) Reporting, and Corporate Social Responsibility (CSR) Reporting. GRI strives to continue developing the "framework for sustainability reporting," and the G4 Guidelines are officially released on May 22, 2013 (Initiative, 2013).

Also, there is an annual agenda of the "Indonesia Sustainability Reporting Award (ISRA)" which is an award given to Indonesia-operated companies that have contributed reporting on corporate activities concerning environmental, social and economic aspects either published separately or integrated into the annual report to maintain the company's sustainability. The yearly award is held in cooperation with the National Center for Sustainability Reporting (NCSR), the Indonesian - Netherlands Association and the Indonesian Institute of Management Accountants. ISRA is conducted annually on a regular basis since 2005.

Regarding the issue of sustainability reports, (Lourenço, Callen, Branco, \& Curto, 2014) study found that companies with a sustainable reputation have higher market values. Similarly, research results in (Bartlett, 2012). For research in Indonesia, (Basri, 2019) found that the ISRA award does not affect the abnormal return and stock trading volume

The focus of this study is to examine the impact of the extent of disclosure of information on the Sustainability Report on the market response to accounting earnings (ECE). ERC is a coefficient that measures the reaction of abnormal return securities to unexpected earnings of companies issuing securities (Naimah \& Utama, 2006). The low earnings return correlation indicates that the earnings information gives little information about the firm's value, or in other words, there is high asymmetry. Therefore, with the aim of reducing information asymmetry, the disclosure of information will be more in companies that have low earnings return correlations, or in other words, the earning returns correlation is negatively related to the area of disclosure (Widiastuti, 2016).

(Widiastuti, 2016) defines Earning Response Coefficient (ERC) as "the sensitivity of stock price changes to changes in accounting profit." The strong market reaction to earnings information as reflected in the high ERC shows the reported earnings quality. On the contrary, the weakness of the market reaction to earnings information as indicated by low ERC shows the reported profit is that of less quality. Although there is a relationship between accounting earnings with stock prices, (Murwaningsari, 2008) argues that the correlation between stock return and profit is very weak and unstable, even profit contribution to predict price and stock return itself is also feeble.

The development of this research is by adding Good Corporate Governance (GCG) as a new variable. The implementation of Good Corporate Governance (GCG) is indispensable to meet the trust of the community and the international world as an absolute requirement for the industry to develop well and healthy the ultimate goal to realize stakeholder value. Based on the above background description, the researcher is interested in conducting research under the title "The Influence of Sustainability Report and Good Corporate Governance Disclosure on Earning Response Coefficient."

\section{Problem Identification}

Based on the described background the problem in this research is identified as follows:

1. Is there any influence of the Sustainability Report Disclosure on Earning Response Coefficient?

2. Is there any influence of Good Corporate Governance disclosure on Earning Response Coefficient?.

\section{Research Objectives and Contributions}

The objectives to be achieved in this research are:

1. To obtain empirical evidence that there is the influence of Sustainability Report Disclosure on Earning Response Coefficient.

2. To get empirical evidence that there is an influence on the implementation of Good Corporate Governance to Earning Response Coefficient.

The research contribution of this research are expected to be used as a reference for policy by company management on SR both in determining the system of SR disclosure and implementation of GCG and also expected to describe annual financial report so that can be used as a reference for investment decision making. 


\section{Theoretical Review}

Signaling Theory

Sustainability report disclosure aims to provide additional information about the company's activities as well as a means to give a signal to stakeholders about the company's concern for the social and the environment. Sustainability report disclosures appropriate and appropriate stakeholder expectations as a signal provided by the management to the public that the company has good prospects in the future and ensure the creation of sustainability development (Puitri, 2013). This signal is expected to be positively received to affect the company's financial performance as reflected in Return on assets, return on equity, and net profit margin.

Signaling Theory is rooted in pragmatic accounting theory that focuses its attention on the influence of information on behavioral change of information (Akis \& SITI, 2012). Such changes include increased profitability of data from corporate Sustainability report disclosure (Soelistyoningrum \& Prastiwi, 2011). The signaling theory emphasizes that the reporting enterprise can improve the profitability of the company through its disclosure reporting (Ahzar, 2013).

\section{Stakeholder Theory}

The concept of corporate social responsibility has come to prominence since the early 1970s, commonly known as stakeholder theory as a collection of policies and practices related to stakeholders, values, legal compliance, public and environmental awards, and business world commitment to contribute to sustainable development. Stakeholder theory begins with the assumption that the value (value) is explicit and undeniable is part of business activities (Freeman \& Phillips, 2002).

Stakeholder theory says that a company is not an entity that only operates for its own sake but must provide benefits to its stakeholders. Thus, the existence of a company is strongly influenced by the support given by stakeholders to the company (Ghozali \& Chariri, 2007).

Corporate social responsibility should go beyond maximizing profits for the benefit of shareholders, but more broadly that the welfare that can be created by a company is not necessarily limited to the interests of shareholders, but also the interests of stakeholders, that is, all parties who are related or

\section{Sustainability Report}

The development of Sustainability report is part of the concept of sustainability development. Sustainability development means that the current development can be fulfilled without necessarily reducing the needs of future generations to meet their needs (Heemskerk, Pistorio, \& Scicluna, 2002).

Sustainability development needs to be implemented because current economic activity tends to damage the global ecosystem and hampers the needs of the next generation (Utama, 1997). The sustainability report is used as one of the company's information media to the stakeholders to support sustainable development.

According to (Elkington, 1998), the disclosure of organizational performance within the Sustainability report focuses on three aspects called Triple bottom line, which consists of economic, social, and environment. Elkington thinks that this is derived from a management science approach that is intended as a way to operationalize corporate social responsibility (Kuhlman \& Farrington, 2010). (Fajarini \& Susanto, 2012) says economists are the most reluctant group in dealing with sustainability issues because they treat sustainability as a matter of economic resources rather than a public issue. The reason why economists are reluctant to recognize sustainability as a general issue is that the concept of sustainability is fundamentally incompatible with conventional economic theory (Michelon \& Parbonetti, 2012).

Sustainability reports are also used by government agencies, for example from the environment ministry to assess the company's performance on the environment in any organization reporting. As in Indonesia, regulations in CSR disclosure can be found in the rules issued by Bapepam and Law 40/2007 on Limited Liability Companies. Disclosure of sustainability reports in the regulations that have been being established as a stand-alone report, although there are still many CSR implementations disclosed along with the annual report of a company (Kusumadilaga, 2010).

\section{Good Corporate Governance (GCG)}

Corporate governance can be simply defined as a system that regulates and controls the company to create valueadded for all stakeholders. Corporate governance is governance that deals with the interaction between government and society. According to the Decree of the Minister of State/Head of the Capital Investment and Development Agency of SOEs. 23/M-PM.PBUMN/2000 on the development of GCG practice in the company (PERSERO), GCG is a sound corporate principle that needs to be applied in the company which is carried out solely to safeguard the interests to achieve the purpose and objectives. The Malaysian High-Level Finance Committee on Good Corporate Governance in Economic \& Business Journal defines Good Corporate Governance as a process and structure used to direct and manage the business and corporate affairs to improve business prosperity and corporate accountability. GCG's primary objective is realizing shareholder value in the long term by taking into account the 
interests of other parties.

(Prior, Surroca, \& Tribó, 2008) defines corporate governance as "a set of provisions that enable the stockholders by exercising the voting power to compel those in the operating control of the firm to respect their interests.", A set of rules that enable shareholders to acquire support that encourages the operational control of the company to align and respect the interests of shareholders. The Cadbury Committee in (Murwaningsari, 2008), argues that corporate governance is a set of rules governing relationships between shareholders, managers of companies, creditor parties, governments, employees and other internal and external interest holders relating to their rights and obligations or, in another word, is a system that regulates and controls the company.

Earning Response Coefficient (ERC)

(Naimah \& Utama, 2006) define the Earning Response Coefficient (ERC) as the effect of every dollar from surprise earnings on stock returns. This shows that ERC is a reaction to the company's earnings. ERC is also called the coefficient of accounting profit sensitivity is the size of stock price changes to changes in accounting profit.

According to (Scott, 2015), several things affect different market responses to earnings: profit persistence, beta, corporate capital structure, profit quality, opportunity growth, and price informativeness. The more persistent and better the earnings quality is, the higher the ERC value will be. If the beta reflects a higher systematic risk, the ERC will be lower (Scott, 2015).

This is because investors will assess earnings now to predict earnings and returns in the future. The riskier the returns in the future, the lower the investors' reaction to the company's unexpected earnings (EU). The company's capital structure also affects the ERC. Increased earnings (before interest) for high-levered companies means that firms are getting better for lenders than for shareholders. Therefore, high levered companies have lower ERCs than low-levered companies (Scott, 2015).

Previous Research

More companies express that the sustainability report can be a strategy to improve their financial performance. One of the theories that explain the company's motivation in showing the sustainability report is the signal theory. (Nuswandari, 2009) research states that the more the companies reveal their reports, the higher the company's expectation of getting a positive signal from stakeholders.

The disclosure of sustainability report aims to provide information on corporate activities as well as a means to give a signal to stakeholders about the company's concern for the social and the environment. Sustainability report disclosure is expected to produce a positive message from stakeholders to maximize the company's finances in the long term (Agustina, 2013). The disclosure of the company's sustainability report is expected to provide concrete evidence that the company's production process is not only profit-oriented but also concerned with social issues, and the environment, to increase stakeholder confidence that will impact on increasing corporate value through increased investment affecting on improvement profit company (Soelistyoningrum \& Prastiwi, 2011).

(Nuzula \& Kato, 2011) studies on Japan-based companies showed that investors responded to corporate SR disclosure. In Indonesia, (Nurdin \& Cahyandito, 2006) research shows that the disclosure of social and environmental themes in the annual report has a significant effect on investors' reactions as measured by abnormal return and stock trading volume. It is consistent with (Sayekti \& Wondabio, 2007) research which states that SR disclosure negatively affects the ERC. (Sayekti \& Wondabio, 2007) reveal that the informativeness of earnings would be higher when there is uncertainty about the prospects of the company in the future.

(Rifani, 2013) found that Good Corporate Governance proxied with CGPI had a positive effect on earnings quality measuring using ERC. Research conducted by (Wulandari \& Wirajaya, 2014) also found the CGPI announcement contained information so responded to by the market. It is seen with the existence of significant abnormal returns around the date of notification.

Framework

Based on the periodization chosen in this study and on the previous description the theoretical framework of this research is described as follows:Extensive Disclosure of Sustainability Report and Good Corporate Governance to Earning Response Coefficient

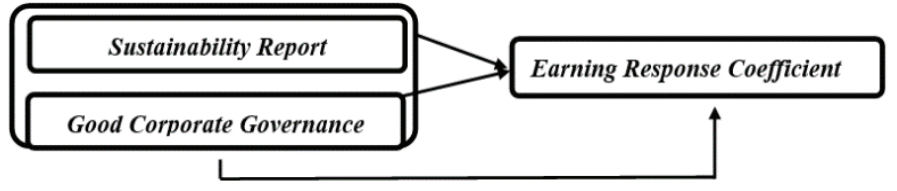

\section{Research Hypothesis}

$\mathrm{H}_{1}$ : Comprehensive Sustainability Report Disclosure Influence on Earning Response Coefficient

$\mathrm{H}_{2}$ : Good Corporate Governance (GCG) Influence on Earning Response Coefficient 


\section{Research Method}

Type of Research

This research uses the causal method, which aims to test the hypothesis on the influence of one or several variables on other variables. The researcher used this research design to provide empirical evidence on the widespread impact of Sustainability Report disclosures and Good Corporate Governance on Earnings Response Coefficient.

Sustainability Report Disclosure

Sustainability report disclosure of business entities is calculated using CSR disclosure index with GRI standard version 4.0 which amounts to 161 items; then it is re-adjusted with each company. The CSRI calculation is performed by giving a score of 1 if one item is disclosed, and 0 if not disclosed. After scoring on all items, the score is then summed to get the overall score for each company. The CSRI calculation formula is:

$$
\operatorname{CSRIj}=\frac{\sum X i j}{n_{j}}
$$

CSI: $\quad$ Corporate Social Responsibility Index company j

¿Xij: Number of items disclosed by company $\mathrm{j}$

NJ: $\quad$ Number of items for companies based on GRI Index 4.0 (161 items)

Good Corporate Governance

Good Corporate Governance in this research is measured using ASEAN CG Scorecard Country Reports and Assessments 2014 utilizing a rating category 1 (179 items). It is because not all companies listed in ASEAN CG Scorecard Country Reports and Assessments apply a two-level assessment. Assessment calculation at each level is as follows:

Level 1. The assessment at level 1 contains five key aspects that refer to OECD principles, and each aspect has 179 items used as a guide. These five aspects are:

Table 1. Structure and Composition Level 1

\begin{tabular}{|l|l|l|l|}
\hline Level 1 & $\begin{array}{l}\text { Number of } \\
\text { Questions }\end{array}$ & $\begin{array}{l}\text { Weight } \\
(\% \text { of total level 1 } \\
\text { Score })\end{array}$ & $\begin{array}{l}\text { Max. } \\
\text { Attainable } \\
\text { Score }\end{array}$ \\
\hline Part A: Rights of Shareholders & 25 & 10 & 10 Points \\
\hline Part B: Equitable Treatment of Shareholders & 17 & 15 & 15 Points \\
\hline Part C: Role of Stakeholders & 21 & 10 & 10 Points \\
\hline Part D: Disclosure and Tranparency & 41 & 25 & 25 Points \\
\hline Part E: Responsibilities of the Board & 75 & 40 & 40 Points \\
\hline
\end{tabular}

(Source: ASEAN CG Scorecard Assesment 2014)

The following equation is used to calculate the level 1 score:

$$
\text { Score }=\frac{\text { No. ofitemsScoredbyPLC }}{\text { Totalno. of Questions }} \times \text { Max. attainablescoreofpart (ponts) }
$$

(Source: ASEAN CG Scorecard Assesment 2014)

Earnings Response Coefficient

The dependent variable in this research is ERC. The quality of good earnings is measured by using the Earnings Response Coefficient (ERC), which is a form of measurement of information content in earnings. ERC is formulated with the following equation:

CARit $=\alpha+\beta$ UEit $+\varepsilon$

where :

CARit: Cumulative Abnormal Return of firm I at time $t$

Unit: Unexpected Earnings of the firm I at time $t$

$\alpha: \quad$ Constants

$\beta$ : $\quad$ The coefficient showing ERC

$\varepsilon: \quad$ Error

In this research, the ERC coefficient is a slope coefficient obtained from a cross-sectional regression between Cumulative Abnormal Return (CAR) as the proxy of the stock price with Unexpected Earning (EU). The abnormal return measurements in this study use the market adjusted models which assume that the best measurement is the market index return (Widiastuti, 2016) so it is not necessary to use the estimation period to form the estimation model, since the estimated security return is the same as the return index markets in the same period. In this case, the market return index uses the return of the composite share price index (CSPI). Here is the formula for calculating abnormal return: 
$\mathbf{C A R}=\Sigma$ ARit

Population and Research Sample

The population used in this research is companies company listed on the Mining Industry Sector with the research period from 2014 to 2016 . The selection is due to that mining companies are directly affected by the issuance of Law No. RI. 40 years 2007. The sampling technique used is purposive sampling. This technique selects specific target groups to obtain information. The sample is sent for certain types of groups that can provide the needed information because the group is the only party who has information or because the group is by the criteria set by the researcher.

Data Collection Technique

The data collection in this research is done in several ways as follows:

1. Documentation, i.e., data collection available on the research object.

2. Library Studies, i.e., from the literature-related problems in writing this research.

Data Analysis Method

Data analysis is done by using the SPSS 23 program including the following analysis:

1. Descriptive Statistics Test

2. Classic Assumption Test consisting of Normality Test, Multicollinearity Test, Heteroskedasticity Test, and Autocorrelation Test

3. Feasibility Test Model consisting of Determination Coefficient Analysis (R2 test), Simultaneous Regression Coefficient Test (F Test) and Partial Test (t-test)

Description of Research Objects

Based on data obtained from the official website of the Indonesia Stock Exchange www.idx.co.id, companies that are included in the criteria for purposive sampling during the year of research (2014-2016) are 37 companies. The criteria set out in the sample selection are shown in Table 4.1

Tabel 2. Sample Selection Results

\begin{tabular}{l|l|l}
\hline No & Sample Determination Results & $\begin{array}{l}\text { Criterion } \\
\text { Amount }\end{array}$ \\
\hline 1. & $\begin{array}{l}\text { Mining companies consistently listed on the IDX during the study period } \\
\text { Companies that do not consistently publish Annual Report during study period } \\
(2014-2016)\end{array}$ & $\begin{array}{l}41 \\
(4)\end{array}$ \\
\hline & Total sample company & 37 \\
\hline & Total sample data (3 years of research) & $\mathbf{1 1 1}$ \\
\hline
\end{tabular}

\section{Results and Discussion}

The data analysis was done by using SPSS 23 program. The method of analysis used in this research includes an analysis of descriptive statistics and multiple regression analysis.

Tabel 3. Descriptive statistics

\begin{tabular}{|l|l|l|l|l|l|}
\hline & $\mathrm{N}$ & Minimum & Maximum & Mean & Std. Deviation \\
\hline SR & 111 & .10 & .98 & .3086 & .16915 \\
GCG & 111 & .13 & 0.89 & .6594 & .86148 \\
ERC & 111 & .02 & 1.59 & .2872 & .28983 \\
Valid N (listwise) & 111 & & & & \\
\hline
\end{tabular}

The CSR variable has a range of values from 0.10 to 0.98 The lowest value range was owned by the PT Citra Mineral Investindo Tbk in 2014 and the highest value was owned by Aneka Tambang Tbk company in 2016. As a world-class company engaged in energy and oil, PT Aneka Tambang Tbk is required not only to produce highquality products but also to carry out environmental management responsibilities. Business actors are required to comply with the provisions of legislation and environmental standards.

The average value of CSR is 0.3038 and the standard deviation is 0.16915 which means the data distribution is not too varied, the data is good enough for the digression, the data distribution tends to approach the average value. If seen from the average variable, the average number of items revealed by the sample company is more or less only 50 items of 161 items that must be disclosed. It indicates that the average sample companies in the Mining Sector from 2014-2016 have not revealed much about CSR activities, so governments in each country need to set rules for the company's reporting CSR specifically in Sustainability Reporting.

The Good Corporate Governance variable has a range of values from 0.13 to 0.89 . The lowest value of Good 
Corporate Governance is owned by Bumi Resource Tbk in 2014. The highest value is owned by Aneka Tambang Tbk company in 2016 of 0.89 . The average value of Good Corporate Governance in the ASEAN CG Scorecard 2014-2016 is 0.6594 , the standard deviation is 0.86148 . It means that the data distribution on the GCG value is not too varied, so the data is good enough to be studied, the data spread is close average. If seen from the average variable, the average total number of items revealed by the sample companies are approximately 121 of 179 items that must be disclosed. It shows the level of achievement of an eligible effort result demonstrates the company's operational appropriateness and regularity with the CG concept. Increasingly, the complexity of business activities in the business world, which means risks and challenges are also potentially increasing. Therefore, the application of GCG principles is necessary so that no parties will be harmed. The GCG implementation is expected to be useful to increase and maximize company value.

The ERC variable has a range of values from 0.02 to 1.59 . The lowest value was by Unilever Indonesia in 2015, this indicates that Unilever in 2015 experienced a lower profit increase from the previous year, resulting in an Unexpected Earnings value of 0.02. The economic slowdown caused product growth in PT Unilever Indonesia Tbk (UNVR) also slows down, thus hampering the purchasing power of Indonesian consumers. In this research, it can be concluded that companies in the sample research during the period 2014-2016 were mostly able to increase profit from the previous year.

Table 4. Normality Test (One-Sample Kolmogorov-Smirnov Test)

\begin{tabular}{|ll|l|}
\hline & & Unstandardized Residual \\
\hline $\mathrm{N}$ & & 45 \\
Normal Parameters ${ }^{\mathrm{a}, \mathrm{b}}$ & Mean & .0000000 \\
& Std. Deviation & 8.1875738 \\
Most Extreme Differences & Absolute & .289 \\
& Positive & .289 \\
& Negative & -.132 \\
Kolmogorov-Smirnov Z & & 1.706 \\
Asymp. Sig. (2-tailed) & & .061 \\
\hline
\end{tabular}

a. Test distribution is Normal.

b. Calculated from data.

The normality test aims to determine whether the data distribution is normal. From the results of the above output, it can be seen that in the Asymp value model. Sig. (2tailed) $=0.061$, then according to the provisions of $0.061>0.05$ the residual value is normal. The data on the model can is deemed normal.

Table 5. Multicollinearity Test

\begin{tabular}{|c|c|c|c|}
\hline \multirow{2}{*}{\multicolumn{2}{|c|}{ Model }} & \multicolumn{2}{|c|}{ Collinearity Statistics } \\
\hline & & Tolerance & VIF \\
\hline \multirow[t]{3}{*}{1} & (Constant) & & \\
\hline & SR & .687 & 1.629 \\
\hline & GCG & .738 & 1.877 \\
\hline
\end{tabular}

a. Dependent Variable: ERC

Based on the results of analysis by using the multicollinearity test contained in table 4.3 , it shows that the VIF value is under 10 , and the tolerance value is above 0.10 . From the test results, it can be concluded that the regression model does not have a multicollinearity problem. 
Table 6. Heteroscedasticity Test

\begin{tabular}{|lll|l|l|l|}
\hline & & SR & GCG & $\begin{array}{l}\text { Unstandardized } \\
\text { Residual }\end{array}$ \\
\hline $\begin{array}{l}\text { Spearman's } \\
\text { rho }\end{array}$ & SR & Correlation Coefficient & 1.000 & .129 & .239 \\
& & Sig. (2-tailed) & .397 & .114 \\
& & $\mathrm{~N}$ & 45 & 45 & 45 \\
\cline { 2 - 6 } & GCG & Correlation Coefficient & .129 & 1.000 & .092 \\
& Sig. (2-tailed) & .397 &. & .547 \\
& $\mathrm{~N}$ & 45 & 45 & 45 \\
\cline { 2 - 6 } & Correlation Coefficient & .239 & .092 & 1.000 \\
& Sig. (2-tailed) & .114 & .547 &. \\
& Residual & 45 & 45 & 45 \\
\hline
\end{tabular}

From the output above, the variable correlation value with Unstandardized Residual has a significance value of more than 0.05 . Because the significance is more than 0.05 , it can be concluded that there is no problem of heteroscedasticity in the regression model.

Table 7. Autocorrelation Test

\begin{tabular}{|l|l|l|l|}
\hline Model & R & R Square & Durbin-Watson \\
\hline 1 & $.336^{\mathrm{a}}$ & .672 & .128 \\
\hline
\end{tabular}

a. Predictors: (Constant), ROA, SR, GCG

b. Dependent Variable: ERC

From the above output, the DW value generated from the regression model is 0.128 , since the DW value lies between $\mathrm{dU}$ and (4-dU) (see DW table), the null hypothesis is accepted, which means there is no autocorrelation in the above model.

\section{Hypothesis testing}

Table 8. Determination Analysis Result

\begin{tabular}{|l|l|l|l|l|}
\hline Model & R & R Square & Adjusted R Square & Std. Error of the Estimate \\
\hline 1 & $.336^{\mathrm{a}}$ & $.672^{\mathrm{a}}$ & .163 & 6.5792 \\
\hline
\end{tabular}

a. Predictors: (Constant) SR, GCG

b. Dependent Variable: ERC

Based on the results of analysis by using the coefficient of determination test contained in table 4.6 shows that the value of Adjusted R Square is equal to 0.672 , this means $67.2 \%$ company performance proxies with the value of Earning Response Coefficient can be explained by sustainability report and Good Corporate Governance, while the remainder $(100 \%-67.2 \%=32.8 \%)$ is explained by other factors beyond this study.

Table 9. F test

\begin{tabular}{|ll|l|l|l|}
\hline Model & & Sum of Squares & F & Sig. \\
\hline 1 & Regression & 1149.964 & 3.143 & $.002^{\mathrm{a}}$ \\
& Residual & 3658.844 & & \\
& Total & 4808.808 & & \\
\hline
\end{tabular}

The simultaneous test that has been through the significance test shows $\mathrm{F}$ count equals 0,000 and 0,000 which means less than the degree of error of 5\%. From the results of such F test, the Sustainability Report and Good Corporate Governance influence Earnings Response Coefficient. 
Table 10. Regression Test Results

\begin{tabular}{|c|c|c|c|c|c|}
\hline \multirow[b]{2}{*}{ Model } & \multicolumn{2}{|c|}{ Unstandardized Coefficients } & \multirow{2}{*}{$\begin{array}{l}\text { Standardized Coefficients } \\
\text { Beta }\end{array}$} & \multirow[b]{2}{*}{$\mathrm{t}$} & \multirow[b]{2}{*}{ Sig. } \\
\hline & $\mathrm{B}$ & Std. Error & & & \\
\hline 1 (Constant) & .140 & .394 & & .877 & .386 \\
\hline SR & .049 & .889 & .222 & .569 & .025 \\
\hline GCG & .056 & .503 & .199 & .303 & .020 \\
\hline
\end{tabular}

The regression equation is as follows:

$\mathrm{Y}^{\prime}=0,360+0,049 \mathrm{X}_{1}+0,056 \mathrm{X}_{2}+\mathrm{e}$

which mean :

Constant of 0.140 means if the sustanaibility report and good corporate governance value is 0 , then Earnings Response Coefficient value is 0.140 .

The variable regression coefficient of the sustainability report is 0.049 ; which means if the sustainability report increases by 1 one-unit then Earnings Response Coefficient will also increase by 0.049 one-unit. The coefficient is positive, which says there is a positive relationship between sustainability report with the Earnings Response Coefficient, the higher the value of sustainability report, the higher the Earnings Response Coefficient is. The significance value of the sustainability report variable in the above table is 0.025 . The significance value is lower than 0.05 , which means the sustainability report has a significant effect on the Earnings Response Coefficient.

The regression coefficient of Good Corporate Governance variable is 0,056; which means that if Good Corporate Governance increases by 1 one-unit, then Earnings Response Coefficient will also increase by 0.056 one-unit. The coefficient is positive, so there is a positive relationship between Good Corporate Governance with the Earnings Response Coefficient. The higher the value of Good Corporate Governance, the higher the Earnings Response Coefficient is. The significance value of the Good Corporate Governance variable in the above table is 0,020. The value smaller than 0.05 , meaning that Good Corporate Governance significantly influences the Earnings Response Coefficient.

\section{Discussion}

In general, the relationship between the level of information disclosure conducted by companies and the company's market performance is still very diverse. Theoretically, there is a positive relationship between disclosure (including voluntary disclosure) and the company's market performance (Sayekti \& Wondabio, 2007). Voluntary disclosure aims to reduce information asymmetry when profit information gives little information about firm value. Sustainability Report is one of the media used by companies to communicate directly with investors. Disclosure of information in Sustainability Reports by companies is expected to reduce information asymmetry and also minimize agency problems (Sayekti \& Wondabio, 2007). (Sayekti \& Wondabio, 2007) examines the influence of CSR information disclosure level in the Sustainability Report on Earnings Response Coefficient (ERC) and provides empirical evidence that CSR information disclosure rate positively affects ERC. The results of this research indicate that investors appreciate the CSR information disclosed in the company's Sustainability Report. A study examining the influence of the Sustainability Report disclosure on ERC was also conducted by (Widiastuti, 2016). This study shows results consistent with predictions about the broad importance of voluntary disclosure in the Sustainability Report on the ERC.

Based on the test, the regression analysis and t-test result prove that an excellent Sustainability Report and Good Corporate Governance influence the Earnings Response Coefficient. It shows that in investing, besides being influenced by the company's profitability, investors are also affected by Good Corporate Governance (GCG) to realize corporate social responsibility as a representation of the company's concern for the interests of stakeholders.

\section{Conclusion}

Based on the result of the analysis which has been done in this research, it can be concluded that:

1. Thee disclosure of Corporate Social Responsibility (CSR) in a sustainability report significantly influences the Earnings Response Coefficient.

2. The Implementation of Good Corporate Governance has a significant effect on the Earnings Response Coefficient.

Limitations and Suggestions

1. Scores of Corporate Social Responsibility disclosure index, as well as an index of annual Good Corporate Governance assessment, was assessed by the researcher based on the interpretation of the company's annual report, making it possible to differentiate the valuation between companies due to the subjective interpretation of the research. Management should be required to make a separate report to report CSR activities and the 
implementation of GCG, which has been supplemented with an index score that is used as a reference by each company. So there is no difference in interpretation in the assessment.

2. The independent variables studied in this study are only disclosure of Corporate Social Responsibility and Good Corporate Governance and the dependent variable is ERC. Influence of an independent variable to a dependent variable only able to explain equally to $67.2 \%$. In the future to the next researcher, for research on Earnings Response Coefficient, it is advisable to add other variables that may affect Earnings Response Coefficient such as profit persistence, capital structure, and systematic risk

\section{References}

Agustina, S. (2013). Pengaruh profitabilitas dan pengungkapan corporate social responsibility terhadap nilai perusahaan. Jurnal Akuntansi, 1(1).

Ahzar, F. A. (2013). Pengungkapan Islamic Social Reporting pada Bank Syariah di Indonesia. Universitas Muhammadiyah Surakarta.

Akis, A. R., \& SITI, M. (2012). Pengaruh Pengumuman Indonesia Sustainability Reporting Award (ISRA) terhadap Abnormal Return dan Volume Perdagangan Saham (Studi Kasus pada Perusahaan Peraih Penghargaan ISRA 2009-2010). Fakultas Ekonomika dan Bisnis.

Aryanti, G. A. P. S., \& Sisdyani, E. A. (2016). Profitabilitas Pada Earnings Response Coefficient Dengan Pengungkapan Corporate Social Responsibility Sebagai Variabel Pemoderasi. E-Jurnal Akuntansi, 171-199.

Bartlett, B. D. (2012). The effect of corporate sustainability reporting on firm valuation.

Basri, H. (2019). Does Indonesia Sustainability Reporting Award (ISRA) cause abnormal return and stock trading volume.

Chariri, A., \& Nugroho, F. A. (2009). Retorika Dalam Pelaporan Corporate Social Responsibility: Analisis Semiotikatas Sustainability Reporting Pt Aneka Tambang Tbk.

Elkington, J. (1998). Partnerships from cannibals with forks: The triple bottom line of 21 st-century business. Environmental quality management, 8(1), 37-51.

Fajarini, I., \& Susanto, A. (2012). Pengaruh Biaya Politis, Leverage, dan ROE Terhadap Pengungkapan Pertanggung Jawaban Sosial Pada Perusahaan Manufaktur di Bursa Efek Indonesia. Paper presented at the Eco-Entrepreneurship Seminar \& Call Paper.

Freeman, R. E., \& Phillips, R. A. (2002). Stakeholder theory: A libertarian defense. Business ethics quarterly, 12(3), 331-349.

Ghozali, I., \& Chariri, A. (2007). Teori akuntansi. Semarang: Badan Penerbit Universitas Diponegoro.

Heemskerk, B., Pistorio, P., \& Scicluna, M. (2002). Sustainable development reporting: Striking the balance: World Business Council for Sustainable Development.

Initiative, G. R. (2013). Global Reporting Initiative 4.0. Reporting Principles and Standard Disclosures.

Kothari, S. P., \& Zimmerman, J. L. (1995). Price and return models. Journal of Accounting and economics, 20(2), 155-192.

Kuhlman, T., \& Farrington, J. (2010). What is sustainability? Sustainability, 2(11), 3436-3448.

Kusumadilaga, R. (2010). Pengaruh corporate social responsibility terhadap nilai perusahaan dengan profitabilitas sebagai variabel moderating (Studi empiris pada perusahaan manufaktur yang terdaftar di Bursa Efek Indonesia). Perpustakaan FE UNDIP.

Lourenço, I. C., Callen, J. L., Branco, M. C., \& Curto, J. D. (2014). The value relevance of reputation for sustainability leadership. Journal of Business Ethics, 119(1), 17-28.

Michelon, G., \& Parbonetti, A. (2012). The effect of corporate governance on sustainability disclosure. Journal of Management \& Governance, 16(3), 477-509.

Murwaningsari, E. (2008). Pengujian Simultan: Beberapa Faktor yang Mempengaruhi Earning Response Coefficient (ERC). Simposium Nasional Akuntansi XI. Pontianak, 23-24.

Naimah, Z., \& Utama, S. (2006). Pengaruh ukuran perusahaan, pertumbuhan, dan profitabilitas perusahaan terhadap koefisien respon laba dan koefisien respon nilai buku ekuitas: Studi pada perusahaan manufaktur di Bursa Efek Jakarta. Simposium Nasional Akuntansi IX, 1, 26.

Nurdin, E., \& Cahyandito, M. F. (2006). Pengungkapan tema-tema sosial dan lingkungan dalam laporan tahunan perusahaan terhadap reaksi investor. Jurnal KLH,(401), 1, 17.

Nurlis, N. (2017). The Influence of Corporate Governance Mechanism and Characteristics on Intellectual Capital Disclosure: A Study of Companies Listed in the Indonesian Stock Exchange. European Journal of Business and Management, 9(20), 49-56.

Nuswandari, C. (2009). Pengaruh corporate governance perception index terhadap kinerja perusahaan pada perusahaan yang terdaftar di Bursa Efek Jakarta. Jurnal Bisnis dan Ekonomi, 16(2).

Nuzula, N. F., \& Kato, M. (2011). Do the Japanese capital markets respond to the publication of corporate social responsibility reports. Journal of Accounting, 1(1).

Prior, D., Surroca, J., \& Tribó, J. A. (2008). Are socially responsible managers really ethical? Exploring the 
relationship between earnings management and corporate social responsibility. Corporate Governance: An International Review, 16(3), 160-177.

Puitri, A. O. (2013). Pengaruh Karakteristik Perusahaan Terhadap Pengungkapan Corporate Social Responsibility (Studi Empiris Perusahaan Penanaman Modal Asing yang Terdaftar dalam Bursa Efek Indonesia Tahun 2010). Universitas Muhammadiyah Surakarta.

Rifani, A. (2013). Pengaruh Good Corporate Governance Terhadap Hubungan Manajemen Laba Dan Kualitas Laba (Studi Empiris Pada Perusahaan Go Public Yang Terdaftar Di CGPI). Jurnal Akuntansi, 1(2).

Sayekti, Y., \& Wondabio, L. S. (2007). Pengaruh CSR disclosure terhadap earning response coefficient. Simposium Nasional Akuntansi X, 1-35.

Scott, W. R. (2015). Financial Accounting Theory Seventh Edition. United States: Canada Cataloguing.

Soelistyoningrum, J. N., \& Prastiwi, A. (2011). Pengaruh Pengungkapan Sustainability Report Terhadap Kinerja Keuangan (Studi Empiris Pada Perusahaan Yang Terdaftar Dalam Bursa Efek Indonesia). Universitas Diponegoro.

Utama, S. (1997). Economic Value Added: Pengukur Penciptaan Nilai Perusahaan. Jurnal Usahawan(4).

Widiastuti, H. (2016). Pengaruh luas ungkapan sukarela dalam laporan tahunan terhadap earnings response coefficient (ERC). Journal of Accounting and Investment, 5(2), 187-207.

Wulandari, K. T., \& Wirajaya, I. G. A. (2014). Pengaruh Pengungkapan Corporate Social Responsibility terhadap Earnings Response Coefficient. E-Jurnal Akuntansi, 355-369. 